\title{
POČÁTKY A VÝVOJ OSÍDLENÍ HORNÍHO MĚSTA PŘÍSEČNICE
}

\author{
JIŘÍ CRKAL - MARTIN VOLF
}

\begin{abstract}
Abstrakt: Přisečnice stála až do 70. let 20. stoleti ve střední části Krušných hor, 20 km severozápadně od Chomutova. Spolu se stavbou údolni nádrže na pitnou vodu bylo město bez dostatečné dokumentace zbořeno. Příspěvek shrnuje dosavadni výsledky studia počátků středověkého osidlení v prostoru Přisečnice. Vedle terénního výzkumu byly znovu zhodnoceny středověké a raně novověké písemné prameny vážicí se $k$ počátkům městečka a hornických areáli̊ v jeho zázemí. Zpracování výsledkủ výzkumu bylo provedeno $v$ rámci mezinárodního interdisciplinárního projektu ArchaeoMontan, který je zaměrenen na poznávání středověkého hornictvi v Krušných horách.
\end{abstract}

Kličová slova: archeologie středověku - Krušné hory - těžba a zpracování rud-dějiny osidlení-projekt ArchaeoMontan.

\section{The Origins and Development of the Settlement in the Mining Town of Př́sečnice}

Abstract: Until the 1970s, Př́sečnice was situated in the central area of the Krušné hory mountains, $20 \mathrm{~km}$ northwest of Chomutov. The town was pulled down without making prior documentation before the construction of a reservoir in the local valley. This paper sums up the existing results of the study of the beginnings of the medieval settlement in the Prisečnice area. Apart from field research, medieval and early modern age written sources related to the origins of the town and the mining areas in its hinterland were reassessed. The processing of the research results was conducted within the ArchaeoMontan international interdisciplinary project focused on the study of medieval mining in the Krušné hory mountains.

Key words: archaeology of the Middle Ages - Krušné hory - mining and processing of ores - settlement history - ArchaeoMontan project.

Studium dějin osídlení Krušných hor v současné době vstupuje do nové fáze. Sídelně historický výzkum se stává jednou z metod poznávání krušnohorské krajiny v rámci projektu ArchaeoMontan. ArchaeoMontan je mezinárodní projekt, který se věnuje výzkumu stř̌edověkého hornictví v saské a české části Krušných hor. ${ }^{1}$ Pro tento projekt je typická spolupráce německých a českých vědců z různých vědních oborů. Od roku 2012 pracují archeologové, historici, zeměměřiči, geologové a informatici po obou stranách hranice na dokumentaci a interpretaci stop středověkého hornictví. Vedle výzkumu v podzemí se odborníci zejména na české straně zaměřují na studium povrchových stop práce a životního prostředí středověkých horníků. Z toho vyplývají otázky směřované na problematiku přípravy, zpracování surovin a obchodu se získanou rudou, přičemž jedním z cílů je rekonstrukce změn životního prostředí v industriální krajině Krušnohoří.

\section{Dosavadní poznatky o vývoji osídlení}

Terénní průzkum na české straně probíhal v letech 2012-2015 v referenčním území vymezeném městy Chomutov, Hora Svatého Šebestiána, Klášterec nad Ohří a Vejprty ve stř̌ední části Krušných hor, $v$ okrese Chomutov. Centrem našich aktivit $\mathrm{v}$ tomto polygonu byl př́sečnický revír, u kterého panoval na základě svědectví písemných pramenů předpoklad, že zde probíhala těžba již ve vrcholném středověku (Crkal-Volf 2014a, 105-117). Centrem této oblasti byla Přísečnice (obr. 1), která představovala důležitý komunikační uzel na dálkové cestě z Čech do Saska. V prostoru pozdějšího hornického města se spojovaly dvě hlavní větve stezek, přičemž první z nich přicházela od Kadaně přes Louchov a druhá od Kralup u Chomutova přes Volyni.

1 Projekt je financován Evropským fondem regionálního rozvoje prostřednictvím Kooperačního programu přeshraniční spolupráce mezi Svobodným státem Sasko a Českou republikou v letech 2014-2020. Na předchozí úspěšný projekt z let 2012-2014 navazuje současný, jehož realizace probíhá v letech 2015-2018. 


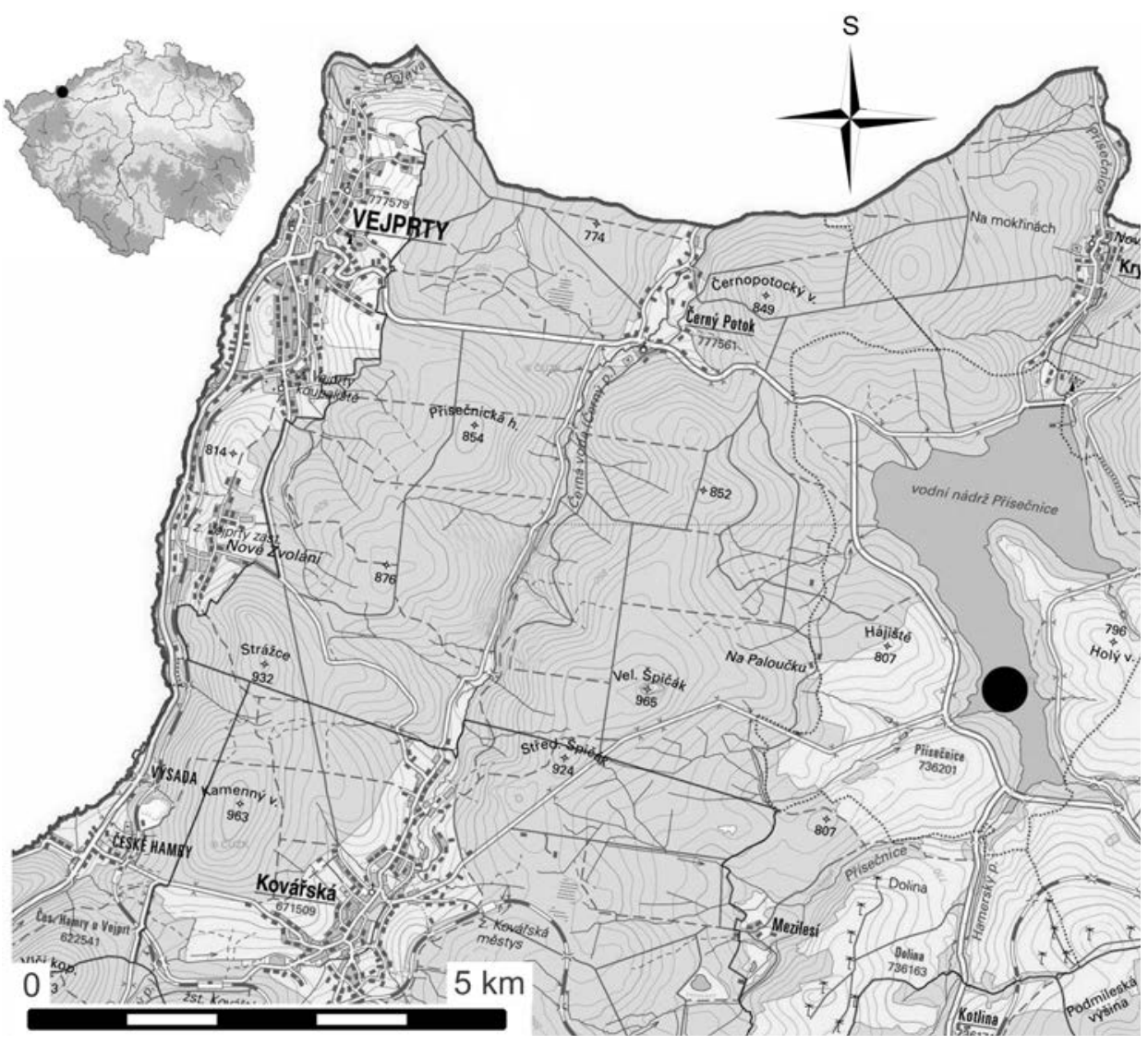

Obr. 1. Př́ísečnice, okr. Chomutov. Výřez z topografické mapy s polohou zatopeného města. Upravil J. Crkal.

Abb. 1. Př́́sečnice, Bezirk Chomutov. Ausschnitt aus einer topographischen Karte mit Lage der gefluteten Stadt. Bearbeitet von J. Crkal.

Z Přísečnice pokračoval tento komunikační koridor přes Schlettau (Slatinu) a Zwickau dále do Saska. S touto cestou jsou neprrímo spojovány zmínky o českém clu ve Zwickau z let 1118 a 1121 (Wissuva 1998, 90). Zpráv o cestě a o clech na ní vybíraných výrazně přibývá od poloviny 14 . století. V souvislosti s touto cestou je město poprvé zmíněno jako oppidum Presnicz v roce 1335 (RBM IV, 71, č. 185). Vedle důležité pozice v nadregionálním obchodním styku hrálo Přísečnicko ve stř̌edověku významnou roli v těžbě a zpracování stř́íbrných a železných rud. To nám dokládá nově nalezený opis listiny z roku 1339, kterou Jan Lucemburský a jeho syn Karel upravují rozdělení výnosů zdejších stříbrných dolů a dalších statků (Balášová-Burkhardt 2014, 167-174). Dosavadní historické bádání o městě bylo silně ovlivňováno zprávou z roku 1583, podle které měla původně Př́ísečnice stát na vrchu Kremsiger, kde během husitských válek osídlení zaniklo, a Přísečnice se následně přesunula na své současné místo (Kloub 2010, 104).

Výše nastíněný rámec vývoje osídlení a počátků těžby na Př́ísečnicku nebyl a není všeobecně uznáván, a na odlišné varianty interpretace upozorňovali již němečtí badatelé. Pokus o objasnění této otázky byl jedním z hlavních impulzů pro terénní výzkum na Př́sečnicku. Ten byl ovšem mimořádně komplikován faktem, že město zcela zaniklo a bylo z podstatné části zatopeno vodami přehradní nádrže vzniklé v 70. letech minulého století. Během vlastní likvidace města proběhl časově a prostorově omezený záchranný archeologický výzkum pod vedením Evy Lehečkové (později Černé). Při výzkumu se nepodařilo zachytit žádné objekty z vrcholného středověku, do „této doby se hlásí jen zlomky nalézané v sekundárnich situacích“ (Černá 2014, 75). 
Jedinou archeologicky doloženou středověkou aktivitou v okolí tak zůstává pyrotechnologický objekt na návrší vzdáleném 1,5 km jihovýchodně od města v poloze Graukopf, zachycený v roce 2006 Evou Černou během záchranného výzkumu předcházejícího výstavbě větrných elektráren, který je datován keramickými nálezy do počátku 13. století (Černá 2007).

\section{Výsledky terénního výzkumu v kontextu současné topografie zkoumaného území}

Další poznatky přinesl až současný terénní výzkum. Díky kolísání vodní hladiny v určitých obdobích dochází k odhalování části jeho intravilánu, což umožňuje vstup do míst běžně nepřístupných (obr. 2). Od napuštění nádrže uplynul čas dostatečný na to, aby se již na březích projevila eroze doprovázená vymíláním a splavováním svrchních částí ornice, přičemž v závislosti na sklonu terénu byla ornice z velké části odplavena až na úroveň podloží. Povrchovým sběrem a mikrosondáží bylo zjištěno celkem 28 poloh s archeologickými nálezy, z nich $14 \mathrm{~s}$ nálezy z 13.-15. století (obr. 3). Vedle situací v samém intravilánu města byly středověké nálezy zachyceny i v jeho okolí (Crkal 2013).

Vedle archeologických zjištění byla provedena i stavebně historická analýza hřbitovního kostela sv. Mikuláše (obr. 4), který bohužel nebyl před svým zbořením podroben standardnímu stavebně historickému průzkumu. Dochovalo se pouze zevrubné zaměření a série fotografií ze sklonku 19. století až 60. let 20. století. Na základě této dokumentace lze konstatovat, že šlo o orientovanou jednolodní stavbu s obdélnou lodí a čtvercovým presbytářem. Lod' byla plochostropá, presbytář byl zaklenut kř́ížovou klenbou. Štítová zed' v sobě ukrývala schodiště v síle zdi osvětlené dvojicí štěrbinových oken. Chronologicky citlivým článkem je ostění hrotitého portálu v jižní stěně presbytáře kostela. Na základě výše uvedených pozorování lze nejstarší fázi stavby datovat do první poloviny 14. století (Crkal-Volf 2014, 97-98).

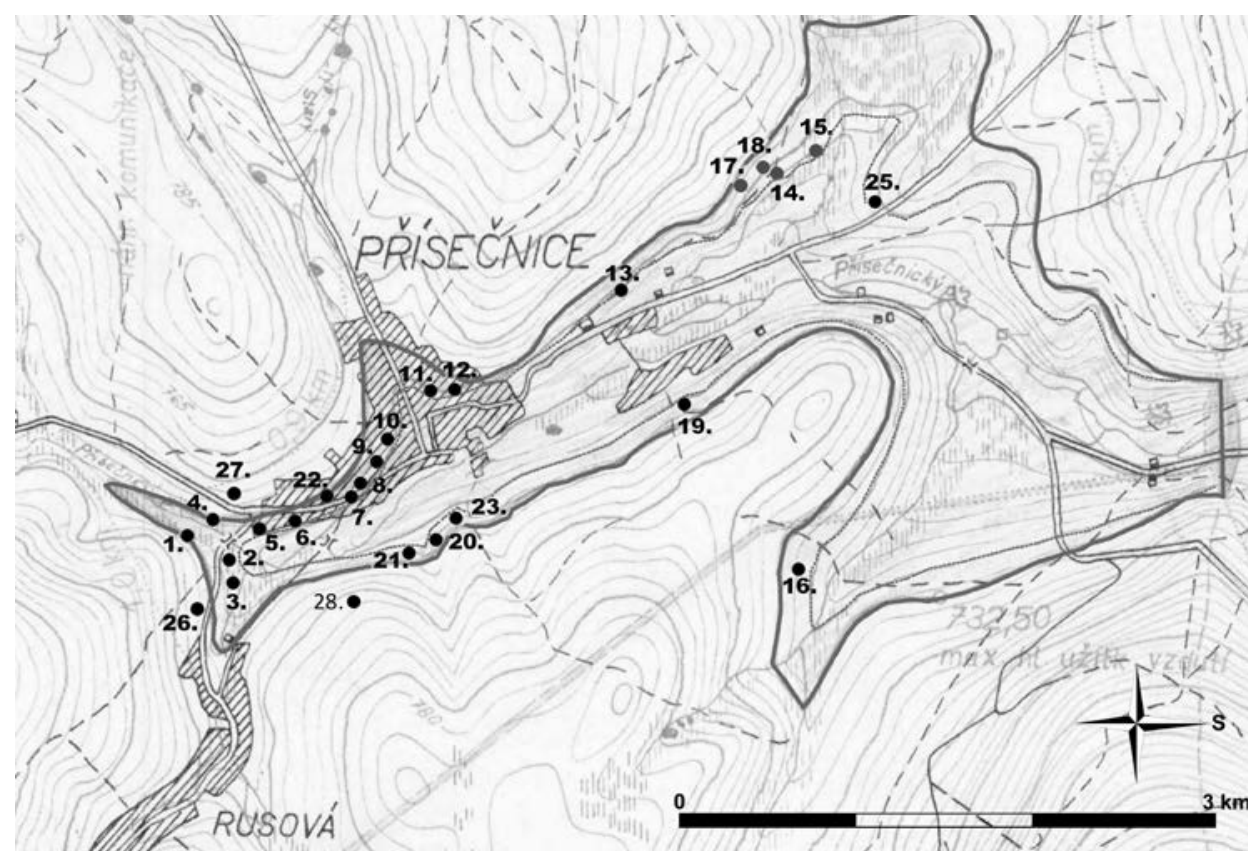

Obr. 2. Př́́sečnice, okr. Chomutov. Výřez z mapy zátopového území KH_SO1_1970 z doby stavby přehrady, čárkovaně vyznačena úroveň poklesu hladiny. Dále vyznačeny polohy s archeologickými nálezy zjištěné sběry v letech $2009-2016$. Upravila Š. Martinková.

Abb. 2. Př́́sečnice, Bezirk Chomutov. Kartenausschnitt des gefluteten Gebiets KH_SO1_1970 aus der Zeit des Talsperrenbaus, schraffiert gekennzeichnetes Niveau des gesunkenen Wasserspiegels. Ferner eingezeichnete Lagen mit den in den Jahren 2009-2016 durch Oberflächensammlungen gemachten archäologischen Funden. Bearbeitet von Š. Martinková. 


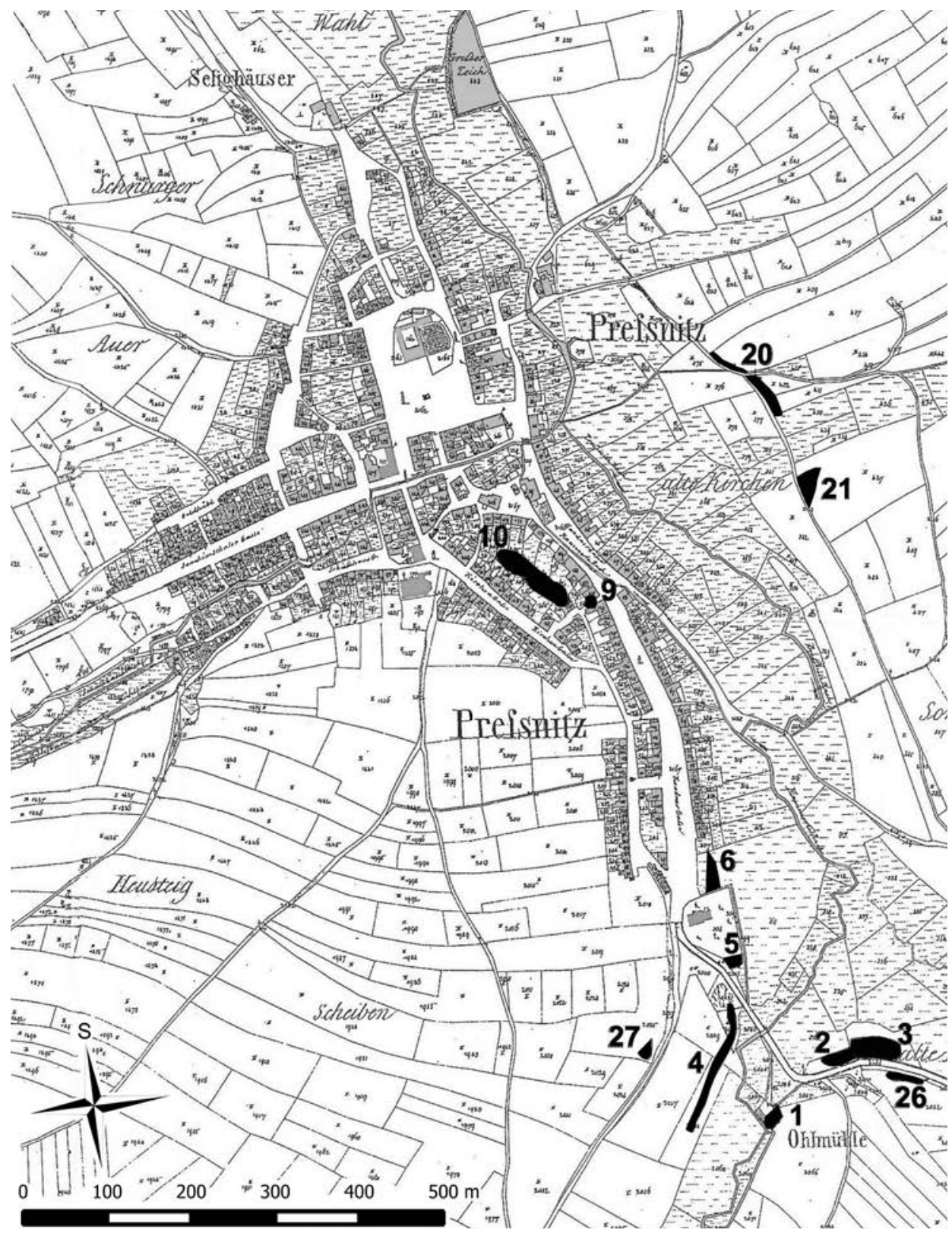

Obr. 3. Př́ísečnice, okr. Chomutov. Překreslená mapa Císařského otisku Stabilního katastru s vyznačenými polohami nálezů v rámci intravilánu města. Upravil J. Crkal.

Abb. 3. Př́ísečnice, Bezirk Chomutov. Modifizierte Karte eines Abdrucks des Stabilen Katasters mit eingezeichneten Lagen der im Innenbereich der Stadt gemachten Funde. Bearbeitet von J. Crkal.

V těsné blízkosti kostela sv. Mikuláše na jižním okraji města byly identifikovány dvě polohy (obr. 3, polohy 5, 6) s výraznějším výskytem zlomků keramiky ze 14. století, což podporuje teorii o výstavbě kostela již v tomto období a rovněž je v souladu s první písemnou zmínkou vztahující se ke kostelu (r. 1352, RDP). Dalšími místy s výrazným výskytem materiálu datovaného do 13. až 15. století jsou plochy bývalých zahrad za domy v Kadaňské ulici (obr. 3, polohy 9, 10). 


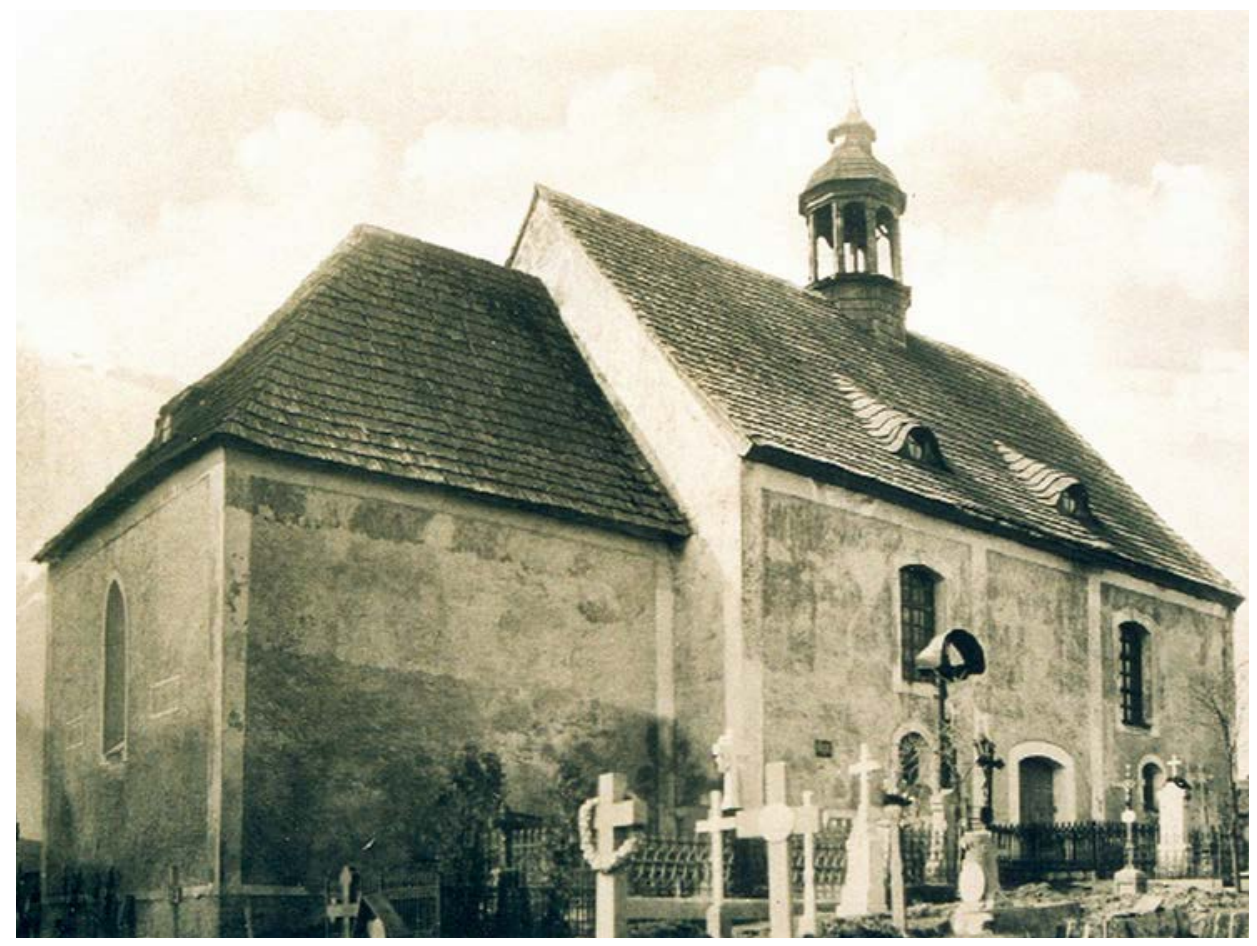

Obr. 4. Přísečnice, okr. Chomutov. Snímek hřbitovního kostela sv. Mikuláše od severu. Foto F. Lederer, konec 19. století, uloženo v Oblastním muzeu v Chomutově.

Abb. 4. Př́́sečnice, Bezirk Chomutov. Aufnahme der Friedhofskirche St. Michael von Norden. Foto F. Lederer, Ende 19. Jhdt., aufbewahrt im Regionalmuseum in Chomutov.

O této ulici se uvažuje jako o původní stř̌edověké lokační, vyměřené při vzniku města. Naproti tomu v místech Školního náměstí a Saumarktu (obr. 3, polohy 11, 12) se nachází jen novověký materiál (od 16. století výše), což indikuje až pozdější osídlení této části města. Žádný datovací materiál nebyl získán na Kostelním náměstí a v Zadní kostelní ulici kvůli značnému množství rozhrnutých kamenných destrukcí, které překryly původní situace, ve Střelnické ulici nalézající se v nivě potoka a pokryté bahnem, a v ulicích Horní kadaňská, Kostelní, Jáchymovská a Zlaté návrší. Ty se nacházející již nad horní hranicí zátopového území, a jejich destrukce jsou zcela nebo z větši části překryty rostlinným a stromovým patrem. Trvale pod vodou se nachází plocha náměstí se zámkem na místě středověké tvrze/hradu a především spodní část Kadaňské ulice a ulic Panské a Masných krámů, což je část města, o níž se někdy uvažuje jako o původním centru místního, možná již předlokačního osídlení (Líbal 1964).

Mimo vlastní intravilán, ale bezprostředně na něj navazující, je řada poloh nacházejících se jižně od vstupu do zaniklého města (obr. 3, polohy 1-4). V prvé z nich (poloha 1), v místě zaniklého mlýna se nachází směs zlomků keramiky od středověké (od 14. století) až po novověk, a dále nálezy strusek. To indikuje jeho středověký původ a původní využití jako hamru nebo tavicí huti. Další dvě polohy mezi silnicí z Rusové a Hamerským potokem charakterizuje velké množství středověkého keramického materiálu, strusek a želez (poloha 2 - 14. až 17. století, poloha 3 - 13. až 15. století, zcela bez novověkých příměsí). Zde je možné předpokládat zaniklou sídlištní polohu při brodu přes Hamerský potok a vyústění staré dálkové cesty do přísečnické kotliny. Výjimečnost tohoto místa spočívá v tom, že jde o první výraznější vodoteč, kterou museli pocestní překonávat po náročném výstupu na hřeben Krušných hor. Další výraznou lokalitou je terénní stupeň nalézající se mezi levým břehem Hamerského potoka a silnicí do Doliny (obr. 3, poloha 4, dále rozdělená na dílčí úseky). Rovněž zde je výrazně zastoupena středověká 
keramika (13. až 15. století, s těžištěm ve 14. století), jen s minimální novověkou příměsí. Doprovázena je rovněž hojným výskytem struskového materiálu. Zde se opět předpokládá zaniklá sídlištní poloha navazující na kostel sv. Mikuláše, využívající výhodnou jižní expozici na terase nad nivou potoka. Vzhledem ke značnému výskytu strusek zde rovněž predikujeme existenci středověkých tavicích hutí. V této poloze byla položena zjištovací sonda, která odhalila ohniště mírně zahloubené do podloží, datované keramickými nálezy na přelom 13. a 14. století. Jde doposud o jediný intaktně dochovaný vrcholně středověký objekt z Př́ísečnice.

Třetím prostorem s velice výrazným výskytem středověkých nálezů jsou polohy na pravém břehu Př́ísečnice v trati Schöne Maria (obr. 3, polohy 20, 21, 28 a částečně 23). Ty leží přímo proti centru města na opačné straně potoční nivy, na terasách ploché úžlabiny se zaniklou vodotečí. Keramický materiál je datován do 13. až 15. století (obr. 3, poloha 20), 14. až 15. století (obr. 3, poloha 21) a do 13. až 14. století (obr. 3, poloha 28), a je doprovázen jen minimální novověkou př́iměsí. V obou polohách je zároveň přítomen struskový materiál, zaznamenán je i nález dovezeného magnetitu. Všechny tyto okolnosti svědčí opět o zaniklých sídlištních polohách doprovázených hutnickou činností.

Několik dalších poloh na rozdíl od předešlých již nemá bezprostřední vazbu na město. Je to především skupina nalezišt' severozápadně od města na východním úpatí vrchu Hájiště (obr. 3, polohy 14, 15, 17, 18). Všechny spojují nálezy struskového materiálu, keramický materiál byl výrazněji zastoupen jen v poloze 15 (14. až 16. století). V poloze 18 byl nalezen pouze jediný zlomek středověké keramiky, ovšem současně i středověká podkova a magnetit. Jihovýchodním směrem od těchto poloh je doložená tavicí hut' (Schmelzhütte), která byla v provozu ještě v 18. století. Nelze tak vyloučit, že jde o odpad z této huti, ale stejně tak může jít o stopu již neznámých hutnických provozů. Zde mohlo probíhat tavení rudy ze starých důlních revírů Kremsiger nebo Auspanner, spojených s místem nálezu svazky úvozových cest.

\section{Historická topografie Př́ísečnice ve středověku a v raném novověku}

Na základě studia historických mapových podkladů, zejména map stabilního katastru lze sledovat základní osnovu urbanistického vývoje městečka. Pro jeho vznik jsou zásadní dva prvky - opevněné sídlo a sakrální stavba.

Hřbitovní kostel sv. Mikuláše, který původně plnil farní funkci, zaujme vedle své stavební podstaty i patrociniem - se stavbami zasvěcenými sv. Mikuláši (poloha 3 na obr. 3) jsou spojovány sídelní útvary (proto)urbánního charakteru s významným trhem (Velímský 1999, 7-62). Spolu s kostelem se v písemných pramenech z poloviny 14. století objevuje i hrad, označovaný jako „castrum“ či „Vesten“. Lokalizován je do místa pozdějšího zámku. Zaujímal nížinnou polohu a v jeho obraně hrála stěžejní úlohu voda (Crkal 2012, 10).

Sakrální stavbou a opevněným sídlem tak máme vymezen prostor, v němž předpokládáme vznik a rozvoj městečka. Jeho půdorysné řešení bylo vázané na trasu komunikace, která odpovídá průběhu pozdější Kadaňské ulice. Ta se v jižní části rozšiřuje do prostoru zvaného Alte Ring, uzavřeného zmíněným kostelem, což je místo předpokládaného původního tržiště. Zástavba je členěna do dvou řad parcel, ve tvaru široké ulicové dispozice. Na základě studia indikačních skic stabilního katastru a snímků leteckého laserového skenování se jeví, že na tuto strukturu reaguje systém lánové plužiny, pozorovatelný zejména v jihozápadním a severovýchodním směru. Z absence bezprostřední návaznosti plužiny na zástavbu vyvozujeme, že nejde o standardní formu lesní lánové vsi, se kterou se setkáváme v sousedství přísečnické plužiny v Rusové i Dolině. Tyto dnes rovněž zaniklé vsi jsou patrně výsledkem jednorázové lokace, která proběhla nejpozději na přelomu 13. a 14. století. Dispozice odkazuje spíše na tzv. vřetenový půdorys (poloha 2 na obr. 3), typický pro městečka vzniklá na komunikaci, u kterých hraje výraznou roli i zemědělství (Kuča 1992, 116).

Středověká a raně novověká hornická činnost, která v intravilánu města probíhala v návaznosti na tok Střelnického potoka, urbanismus výrazně neovlivnila. Její pozůstatky však můžeme dodnes sledovat ve formě odvalů a zavalených ústí štol. Středověké hutnické areály zjištěné 
archeologickým výzkumem se nacházely jihozápadně od kostela sv. Mikuláše a východně od náměstí již na pravém břehu toku Př́sečnice.

Bohužel trvale nepřístupný zůstává prostor předpokládaného předlokačního osídlení, v místech brodu přes Střelnický potok a v Přísečnici v severní části Kadaňské ulice, jižní části nového náměstí a ulice Masné krámy (poloha 1 na obr. 3).

Po vrcholně stř̌edověké etapě vývoje nastává s nástupem renesance nová kapitola ve vývoji městečka. Jeho obraz je nám již dostatečně znám z dostupných pramenů. Př́ísečnice byla na sklonku středověku poddanským městečkem, které spravoval volený rychtář s přísedícími. Z nepřímých pramenů se dozvíme, že Přísečničtí měli právo svobodné porážky, vaření piva a výčepu již před rokem 1524 (Ferdinandeum; Urbáŕ 1533). Otázkou je, zda správa městečka v minulosti disponovala hrdelním právem, na které ukazuje pomístní název Alte Galgenberg. Ten je doložen v roce 1548 západně od města (Urbář 1548). Městečko mělo i právo prodeje soli a vaření piva, které byly nuceny odebírat i sousední vsi (Ferdinandeum; Urbáŕ 1533). Existence krčem ve městě je pravidelně zaznamenávána již od roku 1437 (DD VIII, 134 č. 170). V Přísečnici hrálo významnou roli i zemědělství, o čemž svědčí fakt, že vedle domů jsou zde k roku 1437 a později zmiňovány i dvory kmecí s platy (DD VIII, 134 č. 170).

Možná již za posledních lobkovických majitelů, ale především s př́íchodem Šliků v roce 1533 nastává nový rozmach hornické činnosti. Doprovodným jevem je prudký nárůst počtu obyvatel, což má za následek další urbanizaci města. Zatímco v roce 1533 je zde pouze 24 poplatníkủ daně z pozemků, v roce 1548 již více než 170 (Urbář 1533; Urbář 1548). Někdy v tomto období předpokládáme i reakci na demografický vývoj v podobě lokace pravidelné zástavby jáchymovské ulice a okolí hradu, kdy byla uvažovaná starší zástavba začleněna do podoby pravidelného náměstí. Král Ferdinand I. město převzal roku 1546 a udělil mu statut královského horního města. Připomínkou rozmachu v období renesance byl až do zániku města výstavný kostel Nanebevzetí Panny Marie a řada architektonických detailů měštanských domů, především kamenných ostění vstupních portálů.

\section{Počátky osídlení, vztah Přísečnice a hornického sídliště na Kremsigeru}

V rámci našeho studia jsme se pokusili na základě nových archeologických nálezů a jejich zasazení do historického kontextu znovu zhodnotit téma počátků a vývoje středověkého osídlení v prostoru zaniklého města. Tato kapitola byla vzhledem k likvidaci města a jeho zatopení považována za uzavřenou, avšak díky příznivým okolnostem se ji podařilo znovu otevř́ít. Předkládaná studie mění pohled na počátky a vývoj vrcholně středověkého osídlení na Př́sečnicku. Obraz Přísečnice a jejího okolí, tak jak jej vnímáme prostřednictvím systematické analýzy výpovědi písemných a nově získaných archeologických pramenů, se zásadně změnil. Chápeme jej jako výsledek strukturálních změn, které zde probíhají pravděpodobně již od sklonku 13. století. Př́sečnice nestála $\mathrm{v}$ horské krajině osamocena, již v tomto období se v okolí vyskytovaly montánní areály, především hornické sídliště na tzv. Kremsigeru, ke kterému chybí středověké písemné prameny. Ve velké části syntetických prací věnujících se historii regionu se objevuje předpoklad, že v této poloze stála původní Přísečnice. Výsledky aktuálního bádání v podobě současně probíhajícího výzkumu obou lokalit - hornického sídliště Kremsiger (Balášová a kol. 2012; Derner-Lissek 2014) a samé Přísečnice - přinášejí nový pohled na jejich vztah. Vzhledem k analýze nálezových souborů, konkrétně jejich keramické složky, docházíme k závěru, že existence obou areálů byla zčásti souběžná. Zlomky keramických nádob typických pro závěr 13. a první polovinu 14. století pocházejí jak z Přísečnice, tak z Kremsigeru, a keramická produkce si je vzájemně velice podobná. Shodné jsou technologické stopy, tvarová náplň a výzdoba. Mezi nálezy z Př́ísečnice se však objevuje i archaický materiál, který lze spojovat se starší produkcí hradištní tradice hlásící se do průběhu 13. století. Zatímco horní hranici pro dobu existence sídliště na Kremsigeru představuje polovina 14. století, respektive nálezy z tohoto období, v Př́isečnici se vyskytují artefakty dokumentující pokračující středověký a novověký vývoj lokality (obr. 5 a 6 ). 
1
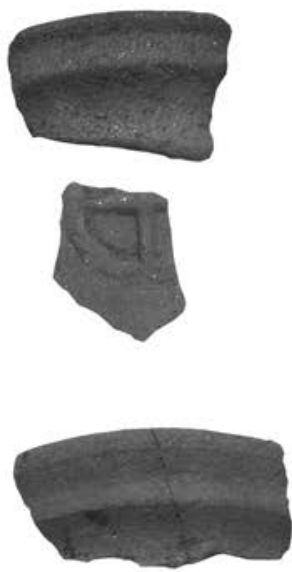

2

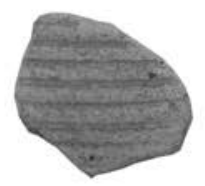

3
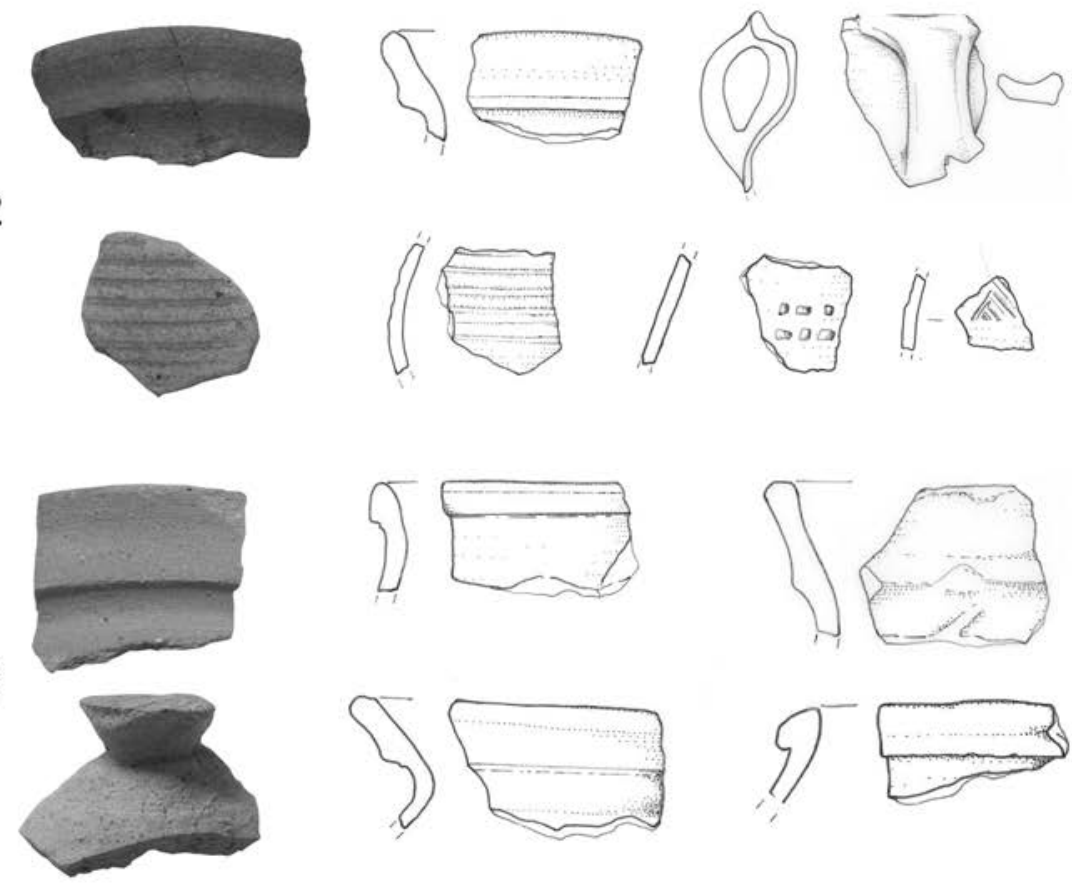
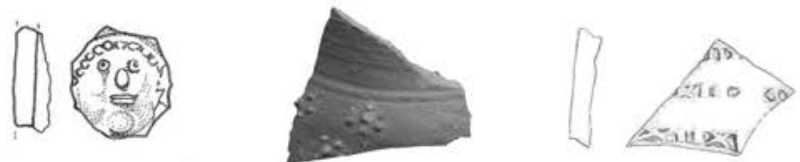

4
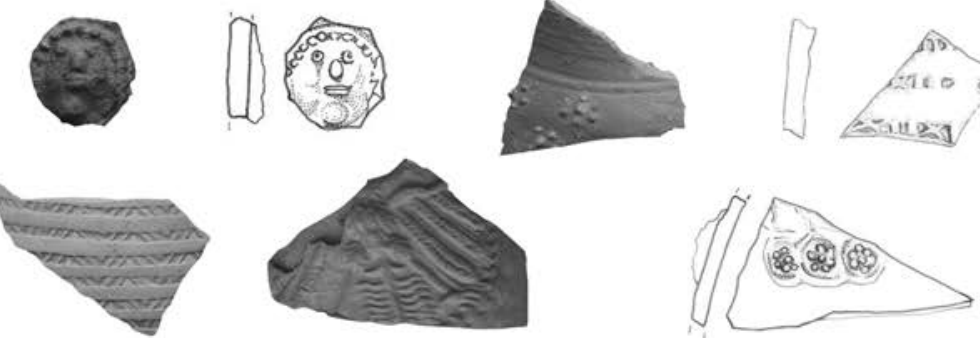

\section{0}

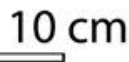

Obr. 5. Přísečnice, okr. Chomutov. Výběr keramických nálezů zařazených do skupin na základě makroskopické a technologické analýzy. Kresba K. Fučíková, upravil M. Volf.

Abb. 5. Př́ísečnice, Bezirk Chomutov. Auswahl der anhand einer makroskopischen und technologischen Analyse in Gruppen unterteilten Keramikfunde. Zeichnung K. Fučíková, bearbeitet von M. Volf. 
Jaký byl tedy vztah Přísečnice a hornického sídliště neznámého jména $\mathrm{v}$ poloze na Kremsigeru (obr. 8), vázaného na exploataci železných a stř́brných rud? Kremsigerem se $\mathrm{v}$ rámci zpracování výsledků výzkumu hornického sídliště zabývá Kryštof Derner (2015), přičemž uvažuje o městském charakteru a právním statutu hornických sídlišt'. Jaké městské rysy tedy nachází u Kremsigeru? Nejvýraznějším je půdorysné řešení lokality, zřejmé v jižní části lokality, kde v hrubých rysech spatřuje vyměření centrálního půdorysu - prostranství obklopené sídlištními objekty (zemnicemi, sklepy či suterény nadzemních budov) mohlo sloužit jako trh, či bylo pouze inspirováno městským předobrazem. Všímá si absence opevnění, které bývá typické pro lokality, kde je doložena těžba stř́bra. Pozorování z Kremsigeru zasazuje do kontextu poznání hornických sídlišt' v Evropě a zabývá se jejich vztahem $\mathrm{k}$ centrům $\mathrm{v}$ jejich okolí. V prrípadě vztahu Př́isečnice a Kremsigeru nabízí dvě základní varianty, přičemž za nepravděpodobnou považujeme možnost, že význam postavení Kremsigeru přešel po jeho opuštění do Př́isečnice. Druhá varianta předpokládá rychlý vývoj Př́ísečnice $\mathrm{v}$ tržní centrum zemědělsko-hornické oblasti doprovázený dočasným vzestupem hornického sídliště na Kremsigeru (Derner 2015, 125), které představovalo výraznou spotřební lokalitu a koncentraci hornických specialistů a prridružených řemesel a služeb. ${ }^{2}$

\section{Model vývoje osídlení}

Vrátíme-li se $\mathrm{k}$ počátkům Př́ísečnice, zaměříme se na období stabilizace sídelní struktury. Předpokládáme, že tento proces je reakcí na změnu právní formy sídliště. $\mathrm{K}$ pochopení této transformace nám chybí písemné prameny, proto při analýze počátků vrcholně středověkého osídlení použijeme pracovní model, který je třeba v průběhu dalšího studia dále ověřovat (obr. 7). S výrazným vzestupem hornických a zpracovatelských aktivit v okolí vyvstává potřeba centrální lokality, která by v sobě spojovala správní, farní a tržní funkci.

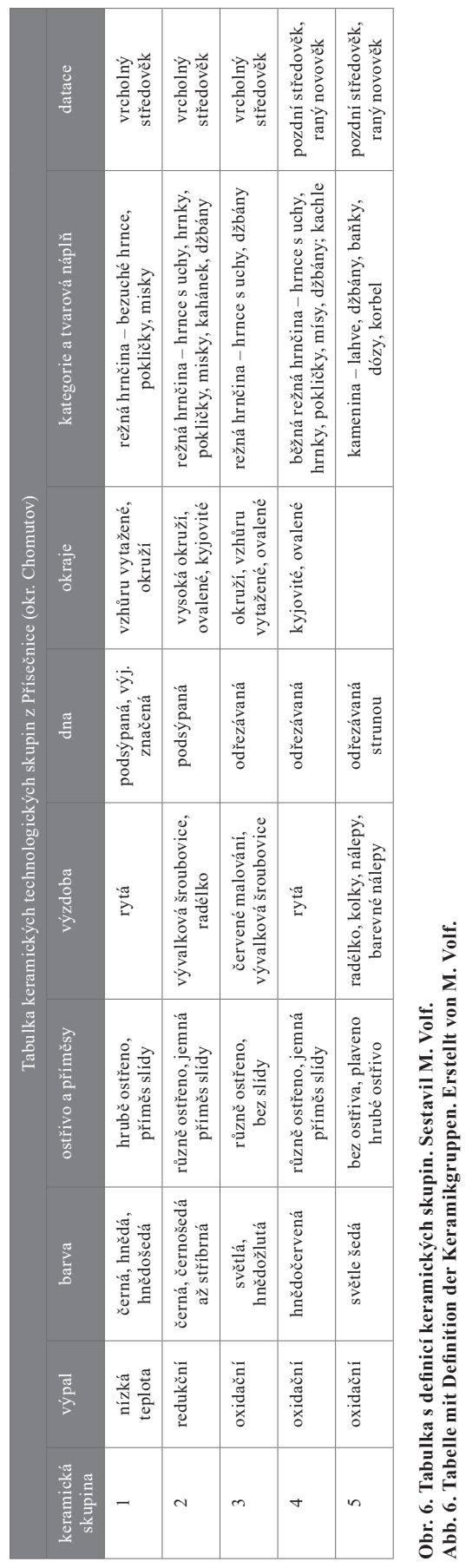

2 Děkujeme kolegovi MUDr. et Bc. Kryštofu Dernerovi za dlouhodobou a neúnavnou diskusi na téma vývoje středověkého osídlení na Př́sečnicku, a dále všem partnerům z projektu ArchaeoMontan za konzultace. 


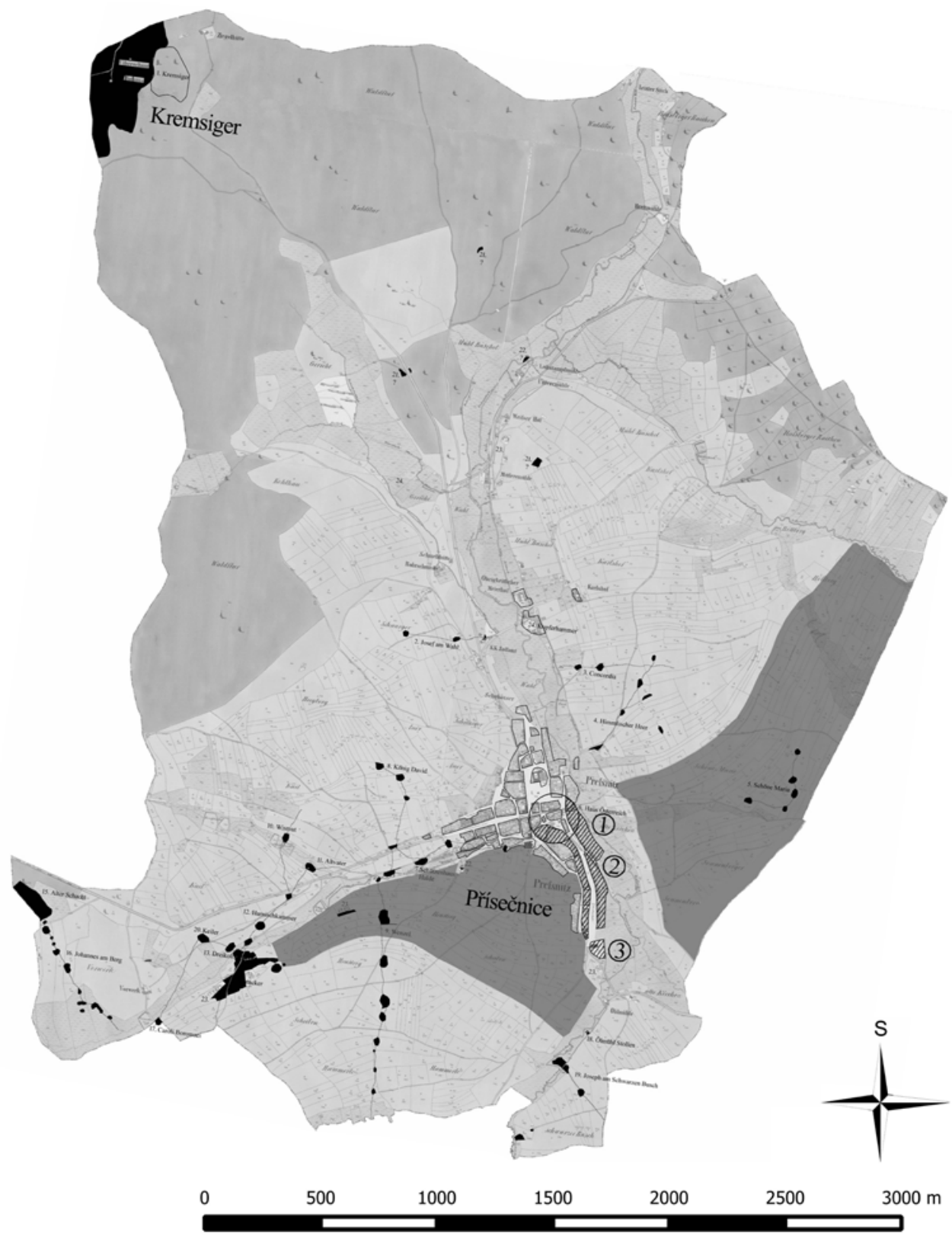

Obr. 7. Přísečnice, okr. Chomutov. Mapa Císařského otisku Stabilního katastru s vyznačeným modelem vývoje stř̌edověkého osídlení lokality. 1 - nejstarší osídlení v podobě etapového bodu na dálkové cestě, 2 - dvouřadá dispozice stř̌edověkého městečka, 3 - kostel sv. Mikuláše. Šedě - stř̌edověká lánová plužina městečka, černě - montánní areály. Sestavili J. Crkal a M. Volf.

Abb. 7. Př́ísečnice, Bezirk Chomutov. Karte eines kaiserlichen Abdrucks des Stabilen Katasters mit eingezeichnetem Entwicklungsmodell der mittelalterlichen Besiedelung der Fundstelle. 1 - älteste Besiedelung in Form eines Etappenpunktes an einem Handelsweg, 2 - zweireihige Anlage der mittelalterlichen Stadt, 3 - St. Michaelskirche. Grau - mittelalterliche Dorfflur, schwarz - Montanareale. Erstellt von J. Crkal und M. Volf. 


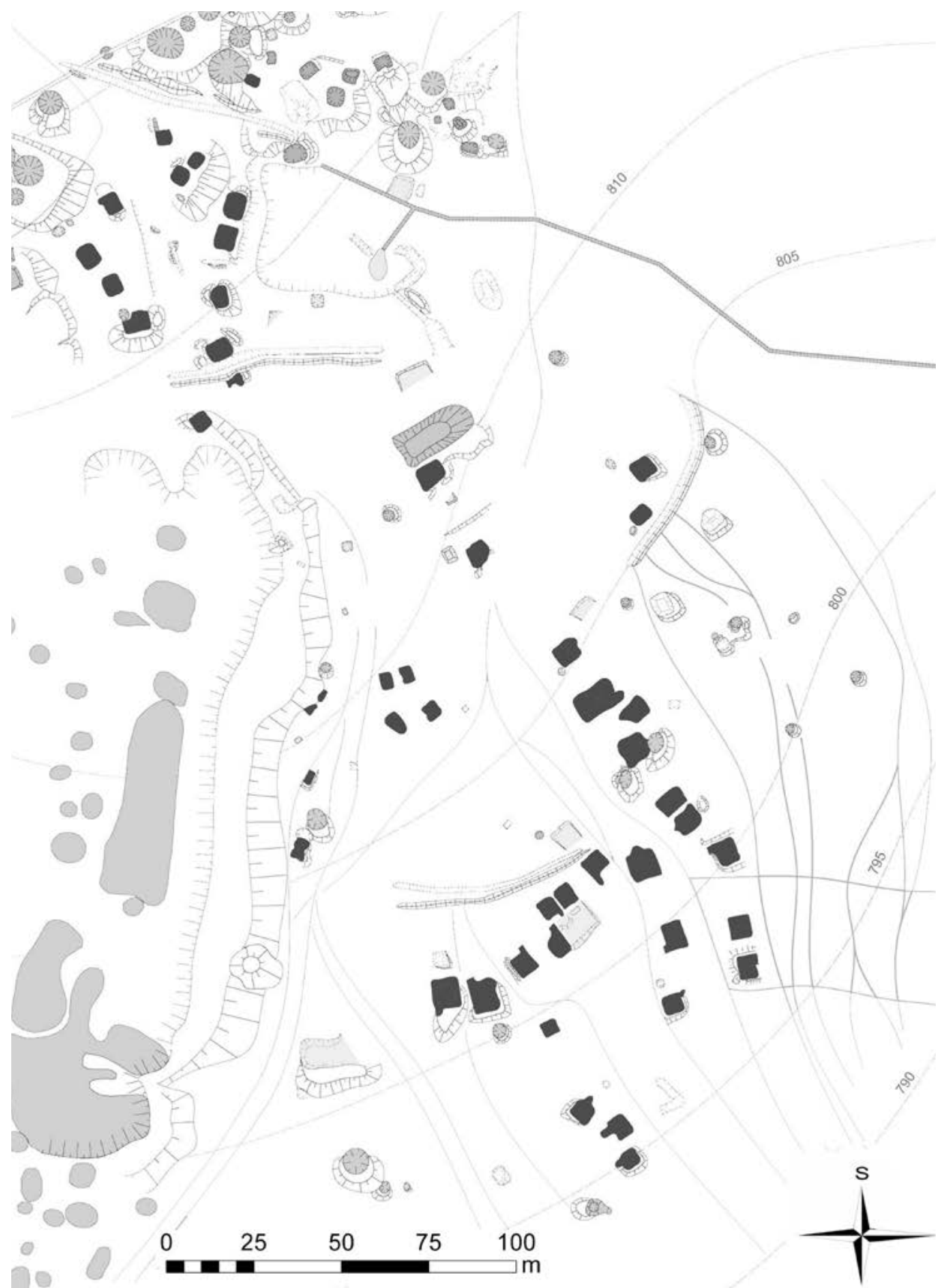

Obr. 8. Př́ísečnice, okr. Chomutov. Hornické sídliště na Kremsigeru. Geodetické zaměření lokality a interpretace objektů, šedě - montánní relikty; černě - sídlištní objekty. Sestavil K. Derner, 2015.

Abb. 8. Př́ísečnice, Bezirk Chomutov. Bergbausiedlung auf dem Kremsiger. Geodätische Vermessung der Fundstelle und Interpretation der Objekte, grau - Montanrelikte; schwarz - Siedlungsobjekte. Erstellt von K. Derner, 2015. 
Původně neuspořádané osídlení, v podobě etapového bodu na dálkové cestě, se někdy na přelomu 13. a 14. století přeměňuje na sídliště s centrální funkcí. Vedle existence cla máme doloženu jak sakrální stavbu s pohřebištěm, tak správní centrum v podobě hradu. V těsné návaznosti na sídliště pracuje řada hutí (obr. 9). V již zmíněné listině vydané roku 1335 je v souvislosti s procházející cestou Př́́sečnice označena jako „oppidum“. Tuto formulaci interpretujeme jako doklad trhu na lokalitě. Jeho existence byla nezbytnou podmínkou fungování a dalšího rozvoje důlních a zpracovatelských areálů, které byly životně závislé na dovozu potravin a dalších komodit. V Př́sečnici se tak setkáváme se všemi důležitými rysy rozvíjejícího se města, které na Kremsigeru nejsou archeologicky ani písemně doloženy. Obdobný model se předpokládá i u hornického sídliště Bleiberg na Treppenahaueru, kde farní a správní funkci plnily blízký kostel a hrad ve Sachsenburgu.

Opis listiny z roku 1339, kterou král Jan Lucemburský uděluje Fridrichovi a Hermanovi ze Šumburku za jejich předchozí činnost výnosy z vybírání cla, šrotéřství, váhy a všech obchodů, obsahuje i zmínky o výnosech z hornické činnosti a důležitou zmínku o povolení trhu (Balášová-Burghardt 2014). S pány ze Šumburka, na které původně královský majetek přešel, se na Kadaňsku poprvé setkáváme až v roce 1302 (RBM II, 1207 č. 2762). Postupně zde vytvořili velké dominium spravované z hradů Perštejn a Hasištejn. Avšak počátky montánní činnosti spadají spolu se strukturální změnou osídlení již do období po polovině 13. století. Stojíme tak před otázkou, zda vše probíhalo v př́mé královské režii, či prostřednictvím šlechty.

Poznávání raných sídelních útvarů protourbánního charakteru doprovázených doklady těžby a zpracování rud představuje nový směr archeologie středověku a obecně i medievistiky. V návaznosti na práci montánních archeologů v Harzu a jiných oblastech západní a jižní Evropy tento směr v našem prostředí reprezentuje práce Petra Hrubého a dalších, kteří odkrývají počátky těžby a zpracování rud na Jihlavsku a na dalších lokalitách na Českomoravské vrchovině. Tradičním centrem středověkého hornictví je Kutná Hora, jejímž počátkům je věnována adekvátní pozornost. Krušné hory, alespoň tedy jejich česká část, zůstávaly v tomto směru dlouho nedoceněny. Věříme, že i nadále bude studium hornictví v Krušných horách přinášet důležité poznatky o tom, jak se vyvíjelo využívání horské krajiny ve středověku. Význam nových zjištění roste $\mathrm{v}$ jejich konfrontaci s poznatky sídelně historickými, a opuštěné hvozdy a planiny Krušnv́ch hor se tak přeneseně stávaií prostorem celoevropské interdisciplinární diskuse.

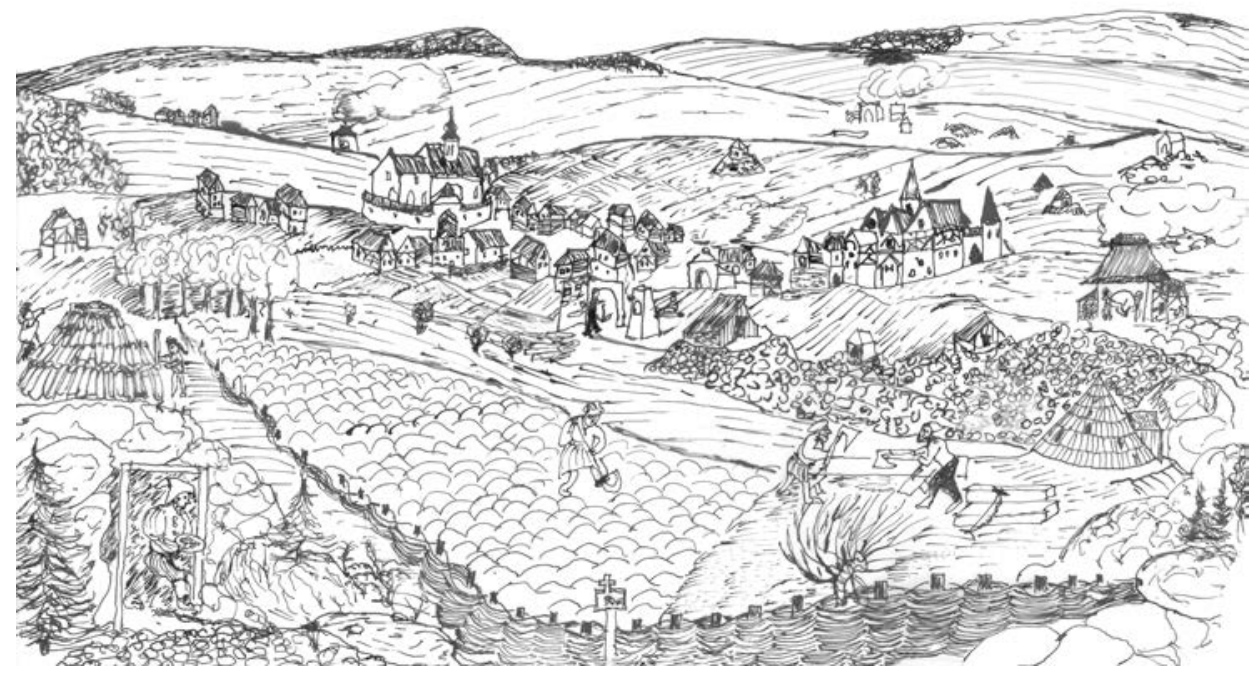

Obr. 9. Př́sečnice, okr. Chomutov. Pokus o rekonstrukci osídlení a montánních areálů v pozdním středověku. Kresba M. Volf. Abb. 9. Př́isečnice, Bezirk Chomutov. Rekonstruktionsversuch der Siedlung und Montanareale im Spätmittelalter. Zeichnung M. Volf. 


\section{Prameny a edice pramenů}

CRKAL, J., 2013: Zpráva o výsledcích povrchových průzkumů v zátopovém území vodní nádrže Přísečnice v letech 2009-2012, č. j. 219/13, ulož. v ÚAPP Most.

ČERNÁ, E.-KÁČERIK, A., 2006: Závěrečná zpráva o záchranném archeologickém výzkumu, č. j. 933/06, ulož. v ÚAPP Most.

DD VIII: Druhá kniha půhonná. In: Desky dvorské. Díl VIII. Druhá kniha půhonná z let 1407-1530 (Friedrich, G., ed.). Praha 1944.

FERDINANDEUM: Tiroler Landesmuseum Innsbruck, fond Ferdinandeum.

LÍBAL, D., 1964: Theze vývoje stavby v českých zemích, SÚRPMO, strojopis, 52-55.

RBM II: Regesta diplomatica nec non epistolaria Bohemiae et Moraviae, Pars II. Annorum 1247-1310 (Emler, J., ed.). Pragae 1892.

RBM IV: Regesta diplomatica nec non epistolaria Bohemiae et Moraviae, Pars IV. Annorum 1333-1346 (Emler, J., ed.). Pragae 1892.

RDP: Registra demarum papalium čili Registra papežských desátků papežských z dioecezí pražské (Tomek, W. W., ed.). Praha 1873.

URBÁR̆ 1548: Register vber die Reumes oden Inwonnern zur Presniczzu Iren heusern des Monats Octobris Anno 48. NA Praha, SM, ka. 909.

\section{Literatura}

BALÁŠOVÁ, M.-CRKAL, J.-ČERNÁ, R.-DERNER, K.-LISSEK, P., 2012: Kremsiger, k. ú. Př́isečnice, okr. Chomutov - současný stav poznání a povrchový průzkum hornického sídliště. In: Archaeomon$\tan$ 2012, Erkunden - Erfassen - Erforschen. Arbeits- u. Forschber. sächs. Bodendenkmalpl. Beih. 26, 69-82. Dresden.

BALÁŠOVÁ, M.-BURGHART, I., 2014: Neznámá listina z roku 1339 jako nejstarší písemný doklad o těžbě stř́bra v českém Krušnohoří. In: ArchaeoMontan 2014. Ergebnisse und Perspektiven / Výsledky a výhledy. Arbeits- u. Forschber. sächs. Bodendenkmalpl. Beih. 29 (Smolnik, R., ed.), 167-174. Dresden.

CRKAL, J., 2012: Tvrz a zámek v Přísečnici. In: Hrady českého severozápadu (Sýkora, M., ed.), 9-37. Most.

CRKAL, J.-VOLF, M., 2014: Počátky města Přísečnice - Die Anfänge der Stadt Preßnitz (Př́́sečnice). In: ArchaeoMontan 2013. Krušná krajina - Erz(gebirgs)landschaft - Ore landscape. Arbeits- u. Forschber. sächs. Bodendenkmalpl. Beih. 28 (Smolnik, R., ed.), 95-108. Dresden.

- 2014a: Terénní průzkumy v české části území projektu Archaeomontan v letech 2012-2014. In: ArchaeoMontan 2014. Ergebnisse und Perspektiven / Výsledky a výhledy. Arbeits- u. Forschber. sächs. Bodendenkmalpl. Beih. 29 (Smolnik, R., ed.), 105-117. Dresden.

ČERNÁ, E., 2013: Archeologie Krušných hor - výpověd’ hmotných pramenů k dějinám města Př́sečnice. In: ArchaeoMontan 2013. Krušná krajina - Erz(gebirgs)landschaft - Ore landscape. Arbeits- u. Forschber. sächs. Bodendenkmalpl. Beih. 28 (Smolnik, R., ed.), 69-82. Dresden.

DERNER, K.-LISSEK, P.-KŘIVÁNEK, R.-ŠREIN, V., 2014: Výzkum hornického sídliště Kremsiger V roce 2013. In: ArchaeoMontan 2014. Ergebnisse und Perspektiven / Výsledky a výhledy. Arbeitsu. Forschber. sächs. Bodendenkmalpl. Beih. 29 (Smolnik, R., ed.), 151-166. Dresden.

DERNER, K., 2015: Kremsiger in the Ore Mountains: a mining settlement, or a town? In: Mining Archeology, perspectives, conflicts, challenges (Silvertant, J., ed.), 107-129. Aichach / Gulben.

KLOUB, J., 2010: Přísečnická mincovna v písemných pramenech 16. a 17. století. In: Comotovia 2009 (Rak, P., ed.), 104-116. Chomutov.

MÜLLER, H.-CRKAL, J.-URBAN, M., 2015: Přísečnice. Horní města Krušných hor (Urban, M., ed.), 244-271. Sokolov.

VELÍMSKÝ, T., 1999: Mikulášské zasvěcení kostelů a počátky trhových sídlišt’ a měst v Čechách. In: Mediaevalia Historica Bohemica VI, 7-62. Praha.

WISSUVA, R., 1998: Die Entwicklungeines Verkehrsnetzes in Sachsen unter besonder Berücksichtigung der Pässedes Erzgebirges und des Vogtlandes, AH 23, 89-95. 


\section{Zusammenfassung}

\section{Anfänge und Entwicklung der Besiedelung der Bergstadt Přísečnice (Pressnitz)}

Im Rahmen des Projektes ArchaeoMontan, das sich mit dem Bergbau des Mittelalters im Erzgebirge beschäftigt, wurde im mittleren Teil des Erzgebirges im Gebiet des Pressnitzer Bergbaureviers eine montanarchäologische Grabung durchgeführt. Dort waren hochmittelalterliche Abbau- und Aufbereitungsareale belegt. Bereits ab Mitte des 13. Jahrhunderts war Pressnitz Zentrum dieses Gebietes. Die Stadt entwickelte sich von einem Etappenpunkt an einem Handelsweg über einen Marktflecken mit Zollstation bis zur Königlich freien Bergstadt in der Renaissance. Ab Mitte des 13. Jahrhunderts nahm die Bedeutung einer Bergbausiedlung auf dem 4 km nordöstlich von Pressnitz gelegenen Höhenzug Kremsiger für einen kurzen Zeitraum zu. Die Beziehung dieser beiden Fundstellen stellt das zentrale Thema des hier vorgelegten Beitrags dar.

Př́isečnice ging in den siebziger Jahren des 20. Jahrhunderts im Zusammenhang mit dem Bau einer Trinwassertalsperre unter. Die Stadt wurde ohne gründliche Dokumentation und ohne entsprechende archäologische Grabung aufgegeben und geflutet. Seit 2007 kam es mehrfach zu einem deutlichen Absinken des Wasserspiegels, was die Durchführung einer Geländegrabung im Innenbereich der Stadt möglich machte. Insgesamt wurden dort 28 Lagen mit archäologischen Funden erfasst, wobei 14 von ihnen aus dem Hochmittelalter stammen. In einigen Fällen wurden mittelalterliche Keramikfunde von Schlackenvorkommen begleitet, was auf Aufbereitungsareale wie Hammerwerke und Hütten hindeutet.

Die hier vorgelegte Studie lenkt die Betrachtung der Anfänge und Entwicklung der hochmittelalterlichen Besiedelung auf Pressnitz. Das Bild von Pressnitz und seiner Umgebung hat sich, so wie es von uns anhand einer systematischen Analyse der schriftlichen Quellen und der jüngst gewonnenen archäologischen Quellen darstellt, grundlegend verändert. Wir verstehen es als Ergebnis von strukturellen Änderungen, die dort wahrscheinlich bereits ab dem 13. Jahrhundert stattgefunden hatten. Pressnitz stand in der Gebirgslandschaft nicht isoliert da. In jener Zeit gab es in seiner Umgebung Montanareale, vor allem die Bergbausiedlung auf dem sog. Kremsiger. In einem großen Teil der zusammenfassenden Arbeiten, die sich mit der Geschichte dieser Region befassen, taucht die Annahme auf, dass Pressnitz sich ursprünglich in dieser Lage befand. Die Ergebnisse der aktuellen Forschung bringen in Form der gleichzeitig an der Bergbausiedlung auf dem Kremsiger und in Pressnitz selbst erfolgten Grabungen eine neue Betrachtungsweise auf die Beziehung zwischen beiden Fundstellen mit sich. Im Hinblick auf die Analyse der Fundkomplexe (konkret ihre Keramikbestandteile) kommen wir zu dem Schluss, dass die Existenz beider Areale teilweise parallel verlief. Bruchstücke von Keramikgefäßen wie sie für das Ende des 13. und die Mitte des 14. Jahrhunderts typisch sind stammen sowohl aus Pressnitz als auch vom Kremsiger. Die Keramikproduktion beider Fundstellen ist sich sehr ähnlich. Auch die technologischen Spuren, der Formengehalt und die Verzierung sind die gleichen. Unter den Funden aus Pressnitz taucht auch archaisches Material auf, dass mit der älteren Produktion der spätburgwallzeitlichen Tradition in Verbindung gebracht werden kann und sich zum Verlauf des 13. Jahrhunderts bekennt. Während die Obergrenze hinsichtlich der Existenz der Siedlung auf dem Kremsiger die Mitte des 14. Jahrhundert, bzw. Funde aus dieser Zeit darstellt, kommen in Pressnitz Artefakte vor, welche eine fortgesetzte mittelalterliche und neuzeitliche Entwicklung der Fundstelle dokumentieren. Im Rahmen unserer Studien haben wir anhand der neuen, in den historischen Kontext gesetzten archäologischen Funde den Versuch unternommen, das Thema der Anfänge und der Entwicklung der mittelalterlichen Besiedelung des Raumes der untergegangenen Stadt neu zu bewerten. Dieses Kapitel war im Hinblick auf die Vernichtung der Stadt und ihre Flutung als abgeschlossen angesehen worden. Aufgrund der günstigen Umstände ist es jedoch gelungen, es wieder zu öffnen. Die Verfasser der hier vorgelegten Studie sind davon überzeugt, dass auch weiterhin das Bestreben fortgesetzt wird, eines der grundlegenden Themen, die das Studium der mittelalterlichen Besiedelung des Erzgebirges bietet, zu verstehen. 
Jiří Crkal, Ústav archeologické památkové péče severozápadních Čech Most, v. v. i., J. Žižky 835, 43401 Most, Česká republika,jiri.crkal@seznam.cz

Bc. Martin Volf, Ústav archeologické památkové péče severozápadních Čech Most, v. v. i., J. Žižky 835, 43401 Most, Česká republika, martin.volf@gmail.com 
